\title{
Polymorphism of growth hormone gene in three goat breeds in Egypt
}

\author{
Karima Fathy Mahrous ${ }^{1 *}$, Sekena H. Abdel-Aziem², Mohamed A. M. Abdel-Hafez ${ }^{2}$, Mohamed Abdel-Mordy ${ }^{3}$ \\ and Hossam E. Rushdi ${ }^{4}$
}

\begin{abstract}
Background: In Egypt, like other developing countries, goats are prime resources of meat. So, selection of goats for superior growth rate is advantageous. Growth hormone $(\mathrm{GH})$ is the main regulator of animal growth, and encoded by GH gene that exhibits active gene variants improving growth. The objective of this study was to identify GH gene variants in three goat breeds (Barki, Damascus, and Zaraibi), via polymerase chain reaction-restriction fragment length polymorphism (PCR-RFLP) and gene sequencing analyses.

Results: Three loci on $\mathrm{GH}$ gene named $\mathrm{GH1}, \mathrm{GH}$, and $\mathrm{GH} 6$ polymorphisms were analyzed. GH1-Haelll/RFLP showed only two genotypes (AB and BB) in all breeds, with absent AA genotype. Both Barki and Zaraibi exhibited the highest GC genotype frequency (0.95). GH2-Haell/RFLP produced only two homozygous genotypes AA in Damascus and BB in both Barki and Zaraibi, with the absence of AB genotype in the three breeds. However, digestion of GH6 by Haelll was monomorphic; it exhibited different single-nucleotide polymorphisms (SNPs), detected by DNA sequencing, among the studied goat breeds.

Conclusions: The revealed SNPs could be employed as useful markers, helping goat breeders in selection of goats for high growth performance. Further analyses with larger sample size are needed for investigating the relationship between the different genotypes and growth traits.
\end{abstract}

Keywords: Goat, Polymorphism, PCR-RFLP, SNP, Growth hormone gene

\section{Background}

Goat is one of the main meat-producing animals in Egypt, and has a considerable contribution to the resource poor section of society for their livelihood (Abdelaziz et al. 1995). There are more than three million heads of goats in Egypt, raised primarily in three regions: the Upper Egypt, Nile Delta, and in the desert rangelands (FAOSTAT 2011). There are about 1.7 million goats, mostly in mixed flocks with sheep, buffalo, and cattle (Galal et al. 2005). In Egypt, there are five indigenous goat breeds: Baladi (the common breed in Nile Delta), Barki or Sahrawi (the predominant breed in desert), Sinaoy (also called Bedouin goat, found mainly in Sinai peninsula), Saidi (distributed widely in Upper Egypt), and Zaraibi (also known as Egyptian Nubian, the common breed in Nile Valley and Delta) (Galal et al.

\footnotetext{
*Correspondence: mahrouskf3@yahoo.com

${ }^{1}$ Genetic Engineering and Biotechnology Research Division, National

Research Centre, Dokki, P.O. 12622, Giza, Egypt

Full list of author information is available at the end of the article
}

2005). Apart of the five goat breeds recognized in Egypt, Anglonubian breed, which is produced through crossing Egyptian Nubian breed with some British breeds (Latif et al. 1987). Genetic improvement schemes of goats in Egypt have also involved different crossbreeding trials with foreign breeds like Damascus goat, which is originated from Syria (Galal 2005).

Growth is an intricate biological process that comprises the regulated coordination of a wide diversity of neuro-endocrine pathways, including a coordinated action of several hormones (like growth, thyroxine, insulin, and prolactin hormones) secreted by the key endocrine glands and controlled by the action of their corresponding genes (Ge et al. 2003; Rasouli et al. 2016; An et al. 2015; Othman et al. 2014; Silveira et al. 2008; Zhang et al. 2013). It is well established that animals with high levels of these hormones exhibit enhanced growth performance (Jia et al. 2014; Sodhi et al. 2007; Sharma et al. 2013; Amie Marini et al. 2010; Ayuk and Sheppard 2006). So, selection of breeding animals based on their 
performance helps to explore superior individuals for growth traits. This superiority could be a result of receiving active gene variant(s) from their ancestors. The study of the structure and function of genes at the molecular level in a breeding population can help to determine the similarity of the genetic material carried by populations and the genetic variation they possess. Several techniques have been evolved to estimate the genetic variance or polymorphism within and among populations (Okumus and Mercan 2007). One of the most commonly used techniques is polymerase chain reaction-restriction fragment length polymorphism (PCR-RFLP). It is a powerful method for detecting nucleotide sequence variance in the amplified deoxyribonucleic acid (DNA).

Growth hormone (GH) plays a vital role in different biological processes, such as growth, metabolism, lactation, and reproduction of farm animal species (Malveiro et al. 2001; Ola et al. 2008; Boutinaud et al. 2003; Seevagan et al. 2015; Katoh et al. 2008; Reinecke et al. 1993). $\mathrm{GH}$ is released from the anterior lobe of pituitary gland, where its main effects are associated with the stimulation of growth of bones and skeletal muscles, through the action of insulin-like growth factor (IGF-1) (An et al. 2011), as well as its great role in milk production (Akers 2006). Consequently, it has been observed that high-yielding animals reveal greater $G H$ levels in comparison to low-yielding ones (Akers 2006). The Caprine GH gene has been mapped on the short arm of goat chromosome 19 (Capra hircus 19q22) (Supakorn 2009). It is encoded by $2.5 \mathrm{kbp}$. Caprine $G H$ gene consists of five exons and four intervening introns (Accession: D00476) (Missohou et al. 2006). The aim of the present study was to screen the genetic polymorphism of goat GH gene in three common goat breeds in Egypt (Barki, Damascus, and Zaraibi) employing two genetic tools; PCR-RFLP and DNA sequencing.

\section{Methods}

\section{Sample collection and DNA extraction}

Blood samples were taken from the jugular vein of 20 healthy animals that represent each 1 of the 3 goat breeds under study; Barki, Damascus, and Zaraibi. All the 60 animals, including males and females, involved in the present study were born and reared in the Agricultural Experiment Station, Faculty of Agriculture, Cairo University. Blood samples were collected in $10 \mathrm{ml}$ tubes containing $2.7 \%$ EDTA as an anticoagulant and kept at $4{ }^{\circ} \mathrm{C}$ till use. Genomic DNA was extracted and purified from whole blood collected samples by salting out procedure illustrated by Miller et al. (1988). The concentration of genomic DNA isolated was measured using Ultraviolet (U.V.) spectrophotometer at wavelength of $260 \mathrm{~nm}$.

\section{Polymerase chain reaction}

Three pairs of primers were used for amplifying GH1, GH2, and GH6 loci of goat GH gene using primers suggested by Amie Marini et al. (2012) (Table 1).

Amplification reaction was carried out in an $25 \mu \mathrm{l}$ volume containing $100 \mathrm{ng}$ genomic DNA, forward and reverse primer (both at concentration $10 \mathrm{pmol} / \mu \mathrm{l}$ ), $1 \mathrm{U}$ Taq polymerase, $2.5 \mu \mathrm{l} \mathrm{Taq} \mathrm{polymerase} \mathrm{buffer,} \mathrm{four}$ dNTPs (each at final concentration of $2.5 \mathrm{mM} / \mu \mathrm{l}$ ), and de-ionized double-distilled $\mathrm{H}_{2} \mathrm{O}$ up to a total volume of $25 \mu \mathrm{l}$. The PCR program included $94{ }^{\circ} \mathrm{C}$ for $10 \mathrm{~min}$, 35 cycles of $95{ }^{\circ} \mathrm{C}$ for $30 \mathrm{~s}, 62^{\circ} \mathrm{C}$ for $30 \mathrm{~s}, 72{ }^{\circ} \mathrm{C}$ for $45 \mathrm{~s}$, and a final extension at $72{ }^{\circ} \mathrm{C}$ for $7 \mathrm{~min}$. The amplicons were analyzed by $1.5 \%$ agarose gel electrophoresis. The gels were stained with ethidium bromide and visualized by U.V. transilluminator.

\section{Restriction fragment length polymorphism}

Restriction fragment length polymorphism (RFLP) was carried out in $15 \mu \mathrm{l}$ of reaction mixture of each sample containing $5 \mu \mathrm{l}$ of PCR product, $9.5 \mu \mathrm{l}$ of $10 \mathrm{X}$ buffer, and $0.5 \mu \mathrm{l}$ of fast restriction enzyme (MBI Fermentas, Germany) specific for each gene (Table 1). The reaction mixture was incubated at $37^{\circ} \mathrm{C}$ for $10 \mathrm{~min}$. The digested products were initially separated by electrophoresis in $2.5 \%$ agarose gel, followed by $12 \%$ polyacrylamide gel. Thereafter, the gels were stained with ethidium bromide. The bands were visualized by U.V. transilluminator. The gels were photographed using digital gel documentation system (ChemiDoc ${ }^{\text {th }}$ XRS+ System with Image Lab ${ }^{\mathrm{Tm}}$ Software from Bio-Rad, USA).

\section{Gene sequence analysis}

PCR products of the tested GH6 locus were purified and sequenced by Macrogen Incorporation (Seoul, Korea). Sequence analysis and alignment were performed using $\mathrm{NCBI} / \mathrm{BLAST} / \mathrm{blastn}$ suite to identify the single-nucleotide polymorphisms (SNPs) among different patterns and alleles.

\section{Statistical analysis}

Genotype and allele frequencies for each locus were calculated using POPGENE Software for Population Genetic Analysis (PopGene version 3.2) (Yeh et al. 1999).

\begin{tabular}{|c|c|c|}
\hline Gene & Primer sequence $\left(5^{\prime} \rightarrow 3^{\prime}\right)$ & PCR product (size and region) \\
\hline GH1 & $\begin{array}{l}\text { CTC TGC CTG CCC TGG ACT } \\
\text { GGA GAA GCA GAA GGC AAC C }\end{array}$ & $422 \mathrm{bp}$ Exons 2 and 3 \\
\hline $\mathrm{GH} 2$ & $\begin{array}{l}\text { TCA GCA GAG TCT TCA CCA AC } \\
\text { CAA CAA CGC CAT CCT CAC }\end{array}$ & 116 bp Exon 4 \\
\hline GH6 & $\begin{array}{l}\text { CCA TCC AGA ACA CCC AGG T } \\
\text { CCA AGC TGT TGG TGA AGA CTC }\end{array}$ & 405 bp Exon 3 \\
\hline
\end{tabular}

$F$ forward, $R$ reverse 
A chi-square test ( $\chi^{2}$ test) was performed on the basis of Hardy-Weinberg law to measure the genetic equilibrium at the population level. Sequence analysis and alignment of sequence products were carried out using NCBI/ BLAST/blastn and BioEdit software in comparison with GenBank Accession numbers to identify single nucleotide substitutions between different detected genotypes.

\section{Results}

Three loci on GH gene named GH1, GH2, and GH6 polymorphisms were analyzed. GH1-flanked a422bp (Fig. 1a). Digestion of this fragment with the restriction enzyme HaeIII resulted in two different alleles, A (uncut $422 \mathrm{bp}$ fragment) and B (366 bp and 56 bp fragments). Only two genotypes, the homozygous $\mathrm{BB}$ (366 bp and $56 \mathrm{bp}$ ) and the heterozygous $\mathrm{AB}$ (422 bp with $366 \mathrm{bp}$ or $56 \mathrm{bp}$ ), were found, with absence of the homozygous genotype AA (Fig. 1b). As shown in Table 2, the genotype $A B$ had the highest frequency in all breeds. Also, the estimates of observed heterozygosity were considerably higher than that of expected heterozygosity for all breeds. Chi-square $\left(x^{2}\right)$ value showed significant deviation from Hardy-Weinberg Equilibrium [HWE] $(P<0.05)$ in both Barki and Damascus goats (Table 2).

Concerning $\mathrm{GH} 2$ gene, PCR produced a DNA fragment of $116 \mathrm{bp}$ (Fig. 1c). Digestion of this fragment with HaelII gave two alleles, A (uncut 116 bp fragment) and B (88 and 28 bp fragments) as shown in Fig. 1d, with a higher frequency of $B$ allele (Table 3). Only two homozygous genotypes, AA (116 bp) and BB (88 and $28 \mathrm{bp}$ ), were found, with absence of AB genotype (116, 88, and 28 bp). All Damascus individuals analyzed showed only the genotype AA. On the other hand, the animals belonging to both Barki and Zaraibi breeds had only the genotype $\mathrm{BB}$ (Table 3 ).

In regard to GH6 gene, the PCR amplification of the gene presented a DNA fragment of 405 bp (Fig. 1e). HaeIII digestion produced only one allele (B), with the absence of allele A. Only one genotype BB (108, 78, 70, $48,44,40$, and $17 \mathrm{bp}$ ) was shown in all breeds studied (Fig. 1f). No polymorphism among the three breeds was detected, indicating the homozygosity of GH6 gene in the goat breeds under study.

DNA nucleotide sequencing of the amplified PCR product of GH6 gene was analyzed in the goat breeds under study (Figs. 2 and 3). As shown in Fig. 3, the sequences of our goats GH6 were aligned with reference sequences for Capra hircus: KU976149, GU355686, KX032517, GU355688, KU935713, KU288612. The sequence alignment of Barki GH6 gene amplicon (ACCN: KU935713.1, Capra hircus) with published sequence showed $98 \%$ identities with two gaps between positions 366 and 369, and six SNPs; (A/G) transition at position $57,(\mathrm{C} / \mathrm{G})$ transversion at position 66 , $(\mathrm{C} / \mathrm{T})$ transition at position $128,(\mathrm{~T} / \mathrm{G})$ transversion at position 282, (A/C) transversion at position 372, and (T/C) transition at position 402. Also, the sequence alignment of

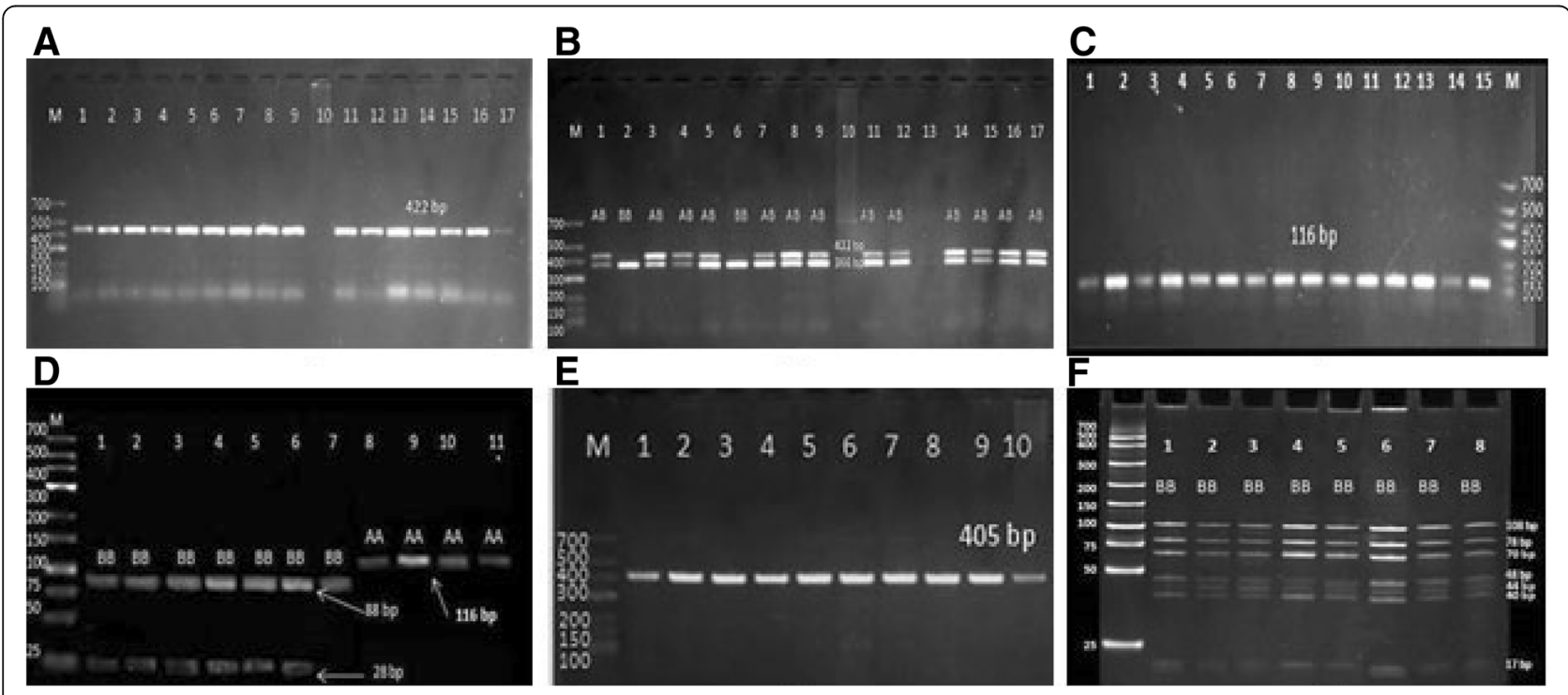

Fig. 1 Electrophoretic pattern of PCR-amplified fragment from three loci on GH gene named GH1, GH2, GH6 and their digestions. a Agarose gel electrophoresis of GH1-PCR fragment (422 bp). Lanes M (25 bp DNA ladder); 1, 2 3, 4, 5, 6 (Barki); 7, 8, 9, 11 (Damascus); and 12, 13, 14, 15, 16, 17(Zaraibi). b Agarose gel electrophoresis of GH1-Haelll/RFLP fragments. Lane M, 25 bp DNA ladder; lanes $(1,3,4,5,7,8,9,11,12,14,15,16,17)$ genotype AB (422, 366, and 56 bp); and lanes $(2,6)$ genotype BB (366 and 56 bp). c Agarose gel electrophoresis of GH2-PCR fragment (116 bp). Lane M, 25 bp DNA ladder. Lanes $(1,2,3,4,5)$ Barki; $(6,7,8,9,10)$ Damascus; and lanes $(11,12,13,14,15)$ Zaraibi breeds. $\mathbf{d}$ Agarose gel electrophoresis Haell/RFLP fragments. Lane M, 25 bp DNA ladder; lanes $(1,2,3,4,5,6,7)$ genotype BB (88 and 28 bp); and lanes $(8,9,10,11)$ genotype AA (116 bp). e Agarose gel electrophoresis of GH6-PCR fragment (405 bp). Lane M, 25 bp DNA ladder. Lanes $(1,2,3)$ Barki; $(4,5,6)$ Damascus; and lanes $(7,8,9,10)$ Zaraibi breeds. f Polyacrylamide gel electrophoresis for GH6-Haell/RFLP. Lane M (25 bp DNA ladder) and $1 \rightarrow 8$ (genotype BB with 108, 78, 70, 48, 44, 40, and 17 bp) 
Table 2 Genotype and allele frequencies, observed heterozygosity (Ho), expected heterozygosity (He), and $x^{2}$ values of GH1 gene digested with Haell

\begin{tabular}{|c|c|c|c|c|c|c|c|c|c|}
\hline \multirow{2}{*}{$\begin{array}{l}\text { Gene } \\
\text { (restriction enzyme) }\end{array}$} & \multirow[t]{2}{*}{ Breed } & \multicolumn{3}{|c|}{ Genotype frequency } & \multicolumn{2}{|c|}{ Allele frequency } & \multirow{2}{*}{$\begin{array}{l}\text { Observed } \\
\text { Het. (Ho) }\end{array}$} & \multirow{2}{*}{$\begin{array}{l}\text { Expected } \\
\text { Het. }(\mathrm{He})\end{array}$} & \multirow[t]{2}{*}{$x^{2}$} \\
\hline & & $\mathrm{AA}$ & $A B$ & BB & A & B & & & \\
\hline \multirow[t]{3}{*}{ GH1 (Haelll) } & Barki & 0.00 & 0.95 & 0.05 & 0.47 & 0.53 & 0.95 & 0.51 & $15.5^{*}$ \\
\hline & Damascus & 0.00 & 0.90 & 0.10 & 0.45 & 0.55 & 0.90 & 0.51 & $12.6^{*}$ \\
\hline & Zaraibi & 0.00 & 0.95 & 0.05 & 0.47 & 0.53 & 0.95 & 0.51 & 12.6 \\
\hline
\end{tabular}

${ }^{*} P \leq 0.05$

Damascus GH6 gene amplicon(ACCN: KU288612.1) with published sequence (Fig. 3) showed 98\% identities with one SNP; (T/C) transition at position 402, and eight gaps; three gaps between positions 363 and 367, two gaps between positions 369 and 372, and three ones between positions 382 and 386. Finally, the sequence alignment of Zaraibi GH6 gene amplicon (ACCN: KU935713.1) with published sequence (Fig. 3) showed 99\% identities with one SNP; (T/C) transition at position 402, and two gaps between positions 382 and 385.

\section{Discussion}

The findings of GH1 gene are in consonance with those reported by Singh et al. (2015) who showed that both of Sirohi and Barbari goat breeds were polymorphic at the GH1 locus treated with HaeIII. Likewise, Othman et al. (2015) detected a SNP $(\mathrm{G} \rightarrow \mathrm{A})$ at position 55 of $\mathrm{GH} 1$ locus (422 bp) in the Egyptian Baladi, Barki, and Zaraibi goat breeds using HaeIII/PCR-RFLP and gene sequencing. Moreover, these results are in agreement with those obtained in Savanna and Kalahari goats by Amie Marini et al. (2012). Furthermore, Hua et al. (2009) studied the polymorphism of GH1 locus in Boer goat bucks, via gene sequencing and PCR-RFLP procedures, and its correlation with growth traits. They stated that the AA genotype (366 and $56 \mathrm{bp})$ resulted in a significant decrease in birth chest girth $(P=0.03)$ and weaning weight $(P=0.014)$, compared to $\mathrm{AB}$ genotype (422, 366 and $56 \mathrm{bp})$. Also, no homozygous $\mathrm{BB}$ (uncut $422 \mathrm{bp}$ ) individuals were identified. The same genetic polymorphism of GH1 was recorded later in Matou and Boer Chinese goat breeds with a significant $(P<0.05)$ larger litter size for $\mathrm{AB}$ genotype $(422,366$, and $56 \mathrm{bp})$ than for AA genotype (366 and 56 bp) (Zhang et al. 2011).

Table 3 Genotype and allele frequencies of GH2-Haell/RFLP

\begin{tabular}{llllllll}
\hline \multirow{2}{*}{$\begin{array}{l}\text { Gene } \\
\text { restriction enzyme) }\end{array}$} & Breed & & \multicolumn{3}{c}{ Genotype frequency } & & \multicolumn{2}{c}{ Allele frequency } \\
& & AA & AB & BB & & A & B \\
\hline GH2 (Haell) & Barki & 0.00 & 0.00 & 1.00 & & 0.00 & 1.00 \\
& Damascus & 1.00 & 0.00 & 0.00 & & 1.00 & 0.00 \\
& Zaraibi & 0.00 & 0.00 & 1.00 & 0.00 & 1.00 \\
\hline
\end{tabular}

Conversely to the results of GH2 locus, Amie Marini et al. (2012) studied the genetic polymorphism of GH2 locus in Savanna and Kalahari goats via PCR-RFLP method. The authors found that both breeds were homozygous for CC genotype (88 and $28 \mathrm{bp}$ ), and that $\mathrm{GH} 2$ gene was monomorphic. Also, Zhang et al. (2011) studiedGH2 gene polymorphism in Matou and Boer Chinese goat breeds by using the same method. They reported that the frequency of CC genotype (88 and $28 \mathrm{bp})$ was significantly $(P<0.05)$ higher than that of CD genotype $(116,88$, and $28 \mathrm{bp})$. Also, litter size for $C C$ genotype was significantly $(P<0.05)$ larger than that for CD genotype. Furthermore, Hua et al. (2009) analyzed the $G H 2$ locus polymorphism in Boer goat bucks, by gene sequencing and PCR-RFLP, and its correlation with some growth traits. They obtained two genotypes CC (88 and $28 \mathrm{bp})$ and CD $(116,88$, and $28 \mathrm{bp})$. The CC genotype was associated with heavier weaning weight than $C D$ genotype.

Reversely to the outputs of GH6 locus, Amie Marini et al. (2012) illustrated the genetic polymorphism of GH6 locus in Savanna and Kalahari goats via PCR-RFLP. They found that both breeds were homozygous for genotype (JJ) $(110,80,70,50,40$, and $23 \mathrm{bp})$, and GH6 gene was characterized as monomorphic. The inconsistency in band sizes between genotype (JJ) and genotype (BB) (108, 78, $70,48,44,40$, and $17 \mathrm{bp}$ ) in the current study may be due to breed difference (i.e., the fact that the different breeds/ populations maintained under the different sets of environmental conditions are subject to different evolutionary forces to varying degree), and may also be the consequence of sampling of breeds understudy. Moreover, the authors detected a substitution of TCC to TCT at position 1148 located in exon three at GH6. This substitution did not change amino acid coding. This detection was done by gene sequencing only in Savanna goats, but not in Kalahari goats due to a limited sample size.

\section{Conclusion}

In this study, PCR-RFLP technique proved to be a convenient tool for screening gene polymorphism. GH1 and $G H 2$ loci were found to be polymorphic, when digested with HaeIII restriction enzyme, among the studied goat breeds; Barki, Damascus, and Zaraibi. These polymorphisms can 
CCATCCAGAACACCCAGGTTGCCTTCTGCTTCTCTGAAACCATCCCAGCCCCCACGAGCAA GAACCAGGCCCAGCAGAAATCAGTGAGTGGCCACCTAGGACCGAGGAGCAGGGGACCTC CTTCATCCTAAGTAGGCTGCCCCAGCTCTCTGCACCGGGCCTGGGGTGGCCTTCTCCCTGA GGTGGCAGAGGGTGTTGGATGGCAGTGGAGGATGATGGTTGGTGGTGGTGGCAGGAGGT CCTCGGGCAGAGGCCGACCTTGCAGGGCTGCCCCGAGCCCGTGGCACCCACCAACCACCC ATCTGCCAGCAGGACTTGGAGCTGCTTCGCATCTCACTGCTCCTTATCCAGTCGTGGCTTG GGCCCGACTGAAGTTCCTCAGCAGAGTCTTCACCAACAGCTTGG

Fig. 2 The sequence analysis of goatGH6 amplified fragment. Forward and reverse primers are shown in red and blue color, respectively

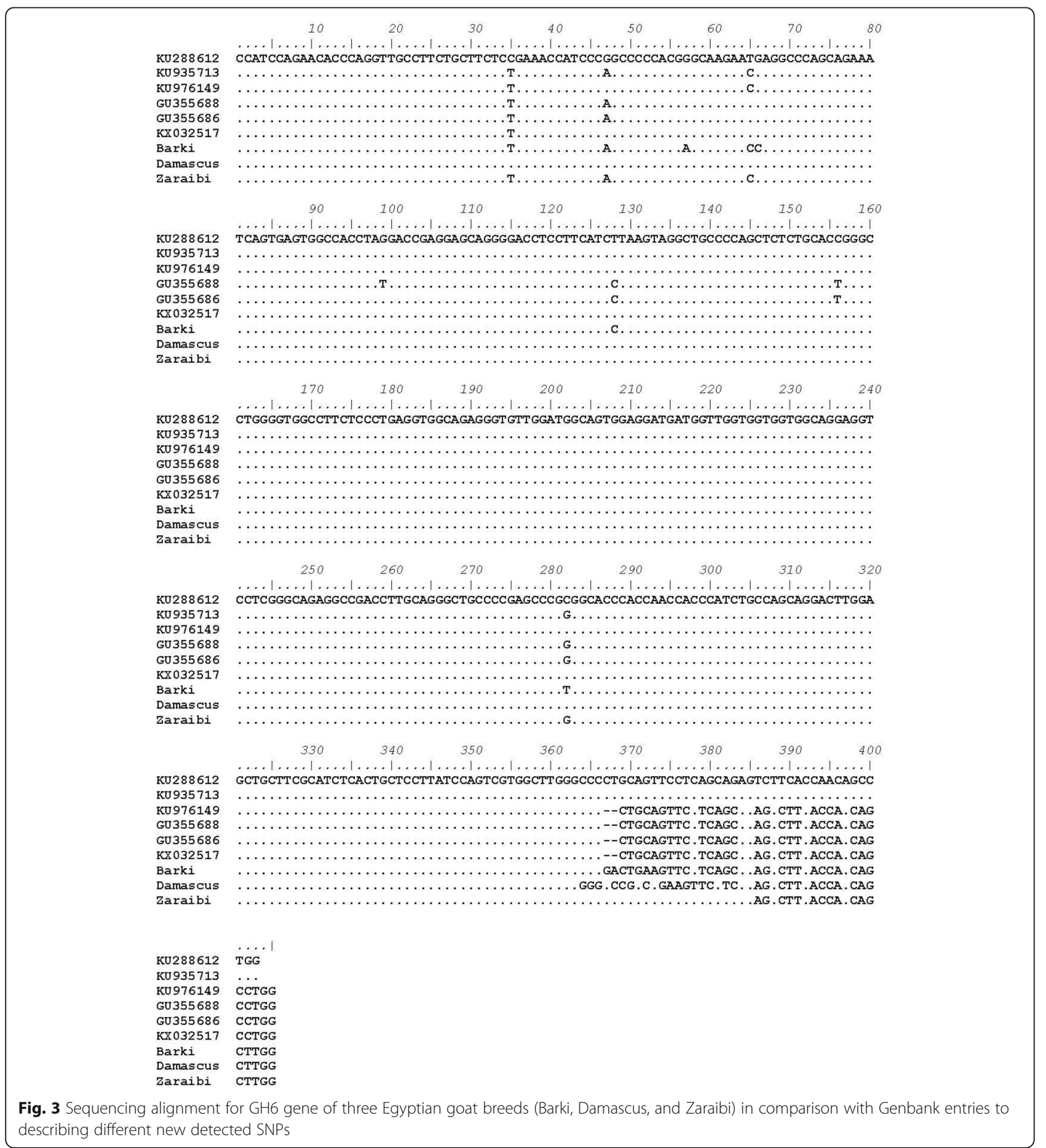


be employed as effective markers for genetic discrimination between goat breeds. Although GH6 locus was monomorphic among the studied breeds when digested with HaeIII, it exhibited different SNPs using DNA sequencing. In the end, this study is considered to be a step advancing for further studies that may add to give additional information about the genetic polymorphism of meat and growth characters of Egyptian goat breeds and the improvement of these economically important traits.

\section{Abbreviations \\ 19q22: A position on the long arm of chromosome 19, region 2, band 2; ACCN: Accession number; AFLP: Amplified fragment length polymorphism; Bankit: A web-based submission tool for GenBank; BL: Length of body; BLAST: Basic Local Alignment Search Tool; bp: Base pair; \\ DNA: Deoxyribonucleic acid; dNTP: A generic term referring to the four deoxyribonucleotides: dATP, dCTP, dGTP, and dTTP; GH: Growth hormone; Haelll: An endonuclease isolated from Haemophilus aegyptius bacteria; IGF- I: Insulin-like growth factor-l; Kbp: Kilobase pairs; M: Molar; NCBI: National Center for Biotechnology Information; OD: Optical density; P: Probability; PCR : Polymerase chain reaction; $\mathrm{pH}$ : Hydrogen ion concentration of a solution; RFLP: Restriction fragment length polymorphism; rpm: Round per minute; SNP: Single nucleotide polymorphism; U: Unit; U.V.: Ultraviolet; w/ v: Weight:volume ratio; $\mu \mathrm{g}$ : Microgram; $\mu$ l: Microliter; $X^{2}$ : Chi-square test; a statistical hypothesis test}

\section{Acknowledgements}

The funding of the NRC to the Ph.D student M.A.M. Abdel-Hafez is greatly acknowledged. The authors are grateful to the Agricultural Experiment Station, Faculty of Agriculture, Cairo University, for the kind help in collecting blood samples required for this work.

\section{Funding}

The design of the study and collection, analysis, and interpretation of data and writing the manuscript were funded by the National Research Centre via PhD fund.

\section{Availability of data and materials}

All data generated or analyzed during this study are included in this published article [and its supplementary information files].

\section{Authors' contributions}

KFM developed the concepts of study, design, and material preparation. KFM and MAM A-H collected the literature research. KFM, SH. A-A, MAM. A-H, MA$M$, and HER analyzed and interpreted the data and manuscript preparation. KFM, SH. A-A, MAM. A-H, and MA-M written the manuscript. AIE and FIE revised the manuscript. All authors read and approved the manuscript.

\section{Ethics approval and consent to participate}

Not applicable.

\section{Consent for publication}

All the authors participated in this manuscript and have read this manuscript and accept publishing it.

\section{Competing interests}

The authors declare that they have no competing interests.

\section{Publisher's Note}

Springer Nature remains neutral with regard to jurisdictional claims in published maps and institutional affiliations.

\section{Author details}

${ }^{1}$ Genetic Engineering and Biotechnology Research Division, National Research Centre, Dokki, P.O. 12622, Giza, Egypt. ²Department of Cell Biology, National Research Centre, Dokki, Giza, Egypt. ${ }^{3}$ Department of Zoology, Faculty of Science, Ain Shams University, Cairo, Egypt. ${ }^{4}$ Department of Animal Production, Faculty of Agriculture, Cairo University Giza, Giza, Egypt.
Received: 4 September 2018 Accepted: 26 November 2018

Published online: 20 December 2018

\section{References}

Abdelaziz NM, Abdelsalam MM, El-Kimary IS, Ibrahim A (1995) Selecting kids of Egyptian Baladi, Angora and Anglo-Nubian breeds under farm conditions. J Agric Sci Mansoura Univ 20:5035-5040

Akers RM (2006) Major advances associated with hormone and growth factor regulation of mammary growth and lactation in dairy cows. J Dairy Sci 89: 1222-1234

Amie Marini AB, Aslinda K, Mohd-Hifzan R (2010) Genetic polymorphism of growth hormone gene in Savanna goat. Proc 31st MSAP Conference, MSAP, Kota Bharu, pp 184-185

Amie Marini AB, Mohd AK, Muhd HR, Faisal AB, Musaddin K (2012) Haell--RFLP polymorphism of growth hormone gene in savanna and Kalahari goats. Mal J Anim Sci 15:13-19

An XP, Hou JX, Lei YN, Gao TY, Cao BY (2015) Polymorphism and DNA methylation in the promoter modulate KISS-1 gene expression and are associated with litter size in goats. AnimReprod Sci 155(4):36-41

An XP, Wang LX, Hou JX, Li G, Song YX, Wang JG, Yang MM, Cui Y, Cao BY (2011) Novel polymorphisms of goat growth hormone and growth hormone receptor genes and their effects on growth traits. MolBiol Rep 38:4037-4043

Ayuk J, Sheppard MC (2006) Growth hormone and its disorders. Postgrad Med J 82(963):24-30

Boutinaud M, Rousseau C, Keisler DH, Jammes H (2003) Growth hormone and milking frequency act differently on goat mammary gland in late lactation. J Dairy Sci 86:509-520

FAOSTAT: FAO Statistical Databases (Food and Agriculture Organization of the United Nations): Statitical yearbook; 2011. http://faostat.fao.org/

Galal S (2005) Biodiversity in goats. Small Rumin Res 60:75-81

Galal S, Abdel-Rasoul F, Anous MR, Shaat IM (2005) On station Characterization of Small Ruminant Breeds in Egypt. In: Iniguez L (ed) Characterization of Small Ruminant Breeds in West Asia and North Africa. ICARDA, leppo, pp 141-193

Ge W, Davis ME, Hines HC, Irvin KM, Simmen RCM (2003) Association of single nucleotide polymorphisms in the growth hormone and growth hormone receptor genes with blood serum insulin-like growth factor I concentration and growth traits in Angus cattle. J Anim Sci 81:641-648

Hua GH, Chen SL, Yu JN, Cai KL, Wu CJ, Li QL, Zhang CY, Liang AX, Han L, Geng LY, Shen Z, Xu DQ, Yang LG (2009) Polymorphism of the growth hormone gene and its association with growth traits in Boer goat bucks. Meat Sci 81:391-395

Jia JL, Zhang LP, Wu JP, Ha ZJ, Li WW (2014) Study of the correlation between GH gene polymorphism and growth traits in sheep. Genet Mol Res 13(3): 7190-7200

Katoh K, Kouno S, Okazaki A, Suzuki K, Obara Y (2008) Interaction of GH polymorphism with body weight and endocrine functions in Japanese black calves. DomestAnimEndocrinol 34:25-30

Latif MG, Abdelsalam MM, Abdelaziz NM (1987) Meat production characteristics of Egyptian Baladi and Angora goats. Meat Sci 20:211-216

Malveiro E, Pereira M, Marques PX, Santos IC, Belo C, Renaville R, Cravador A (2001) Polymorphisms at the five exons of the growth hormone gene in the algarvia goat: possible association with milk traits. Small Rumin Res 41:163-170

Miller SA, Dykes DD, Polesky HF (1988) A simple salting out procedure for extracting DNA from human nucleated cells. Nucleic Acids Res 16:12-15

Missohou A, Talaki E, Laminon IM (2006) Diversity and genetic relationships among seven West African goat breeds. Asian-Austal J Anim Sci 19:1245-1251

Okumus A, Mercan L (2007) Genetic variation at karayaka sheep herds based on random amplified polymorphic DNA (RAPD) markers. Biotech 6(4):543-548

Ola SI, Ai JS, Liu JH, Wang Q, Wang ZB, Chen DY, Sun QY (2008) Effects of gonadotrophins, growth hormone and activin A on enzymatically isolated follicle growth, oocyte chromatin organization and steroidsecretion. MolReprod Dev 75:89-96

Othman OE, Alam SS, Abd El-Aziem SH (2014) Single nucleotide polymorphism in Egyptian cattle insulin-like growth factor binding protein-3 gene. J Gene Eng Biotech 12(2):143-147

Othman OE, Alam SS, Abd El-Kader HAM, Abd El-Moneim OM (2015) Genotyping of growth hormone gene in Egyptian small ruminant breeds. Biotech 14(3): 136-141

Rasouli S, Abdolmohammadi A, Zebarjadi A, Mostafaei A (2016) Evaluation of polymorphism in IGF-I and IGFBP-3 genes and their relationship with twinning rate and growth traits in Markhoz goats. AnnalAnim Sci. https://doi. org/10.1515/aoas-2016-0020 
Reinecke R, Barnes M, Akers R, Pearson R (1993) Effect of selection for milk yield on lactation performance and plasma growth hormone, insulin and IGF-I in first lactation Holstein cows. J Dairy Sci 76:286

Seevagan M, Jeichitra V, Rajendran R, Tirumurugaan KG (2015) Detection of lethal SNP (A781G) in growth hormone (GH) gene of Indian sheep. Small Rumin Res 126:13-15

Sharma A, Dutt G, Sivalingam J, Singh MK, Pathodiya OP, Khadda BS, Dixit SP (2013) Novel SNPs in IGFI, GHR and IGFBP-3 genes reveal significant association with growth traits in Indian goat breeds. Small Rumin Res 115(1):7-14

Silveira LGG, Furlan LR, Curi RA, Ferraz ALJ, Alencar MM, Regitanao LCA, Martins CL, Arrigoni MB, Suguisawa L, Silveira C, Oliveira HN (2008) Growth hormone 1 gene (GH1) polymorphism as possible markers of the production potential of beef cattle using the Brazilian Canchim breed as a model. J Genet Mol Bio 31(4):874-879

Singh PP, Tomar SS, Thakur MS, Kumar A (2015) Polymorphism and association of growth hormone gene with growth traits in Sirohi and Barbari breeds of goat. Vet World 8(3):382-387

Sodhi M, Mukesh M, Prakash B, Mishra BP, Sobti RC et al (2007) Mspl allelic pattern of bovinegrowth hormone gene in Indian zebu cattle (Bosindicus) breeds. Biochem Genet 45:145-153

Supakorn C (2009) The important candidate genes in goats-a review. Walailak J Sci Tech 6(1):17-36

Yeh FC, Boyle T, Rongcai Y, Ye Z, Xian JM (1999) POPGENE, Version 1.31. A Microsoft Window based free ware for population genetic analysis. University of Alberta, Edmonton

Zhang C, Liu Y, Huang K, Zeng W, Xu D, Wen Q, Yang L (2011) The association of two single nucleotide polymorphisms (SNPs) in growth hormone $(G H)$ gene with litter size and superovulation response in goat breeds. Genet Mol Biol 34(1):49-55

Zhang ZJ, Ling YH, Wang LJ, Hang YF, Guo XF, Zhang YH, Ding JP, Zhang XR (2013) Polymorphisms of the myostatin gene (MSTM) and its relationship with growth traits in goat breeds. Genet Mol Res 12(2):965-971

\section{Submit your manuscript to a SpringerOpen ${ }^{\circ}$ journal and benefit from:}

- Convenient online submission

- Rigorous peer review

- Open access: articles freely available online

- High visibility within the field

- Retaining the copyright to your article

Submit your next manuscript at $\boldsymbol{\nabla}$ springeropen.com 